\title{
THE DRAWBACKS AND REFORM OF CHINA'S CURRENT RURAL LAND SYSTEM: AN ANALYSIS BASED ON CONTRACT, PROPERTY RIGHTS AND RESOURCE ALLOCATION
}

\section{Guo-ping He, Hou-qing Luo}

(1) Hainan University, School of Economics and Management

(2) Hainan University, School of Economics and Management

\author{
Guo-ping $\mathrm{He}$ \\ Hainan University \\ School of Economics and Management \\ E-mail: hesy1117@sina.cn \\ Article info \\ Paper category: Preliminary paper \\ Received: 25.8.2015. \\ Accepted: 22.3.2016. \\ JEL classification: $\mathrm{D}_{7}, \mathrm{G}_{2}, \mathrm{~K}_{11}$
}




\begin{abstract}
This article analyzes the drawbacks of China's current rural land system (the Household Contract System based on the collective ownership) mainly from the perspectives of contract, property rights and resource allocation. This article defines the Household Contract System as a lease where the collective (landowner) leases land to its members to farm independently. The drawbacks of China's current rural land system mainly include instability of the peasants' land use right and insecurity of their land income right weakening peasants' enthusiasm for investment in land, and a lot of restrictions on the transfer of peasants' land leases obstructing the flows and optimized allocation of labor, land and capital. According to analysis, the drawbacks of China's current rural land system result mainly from the collective ownership and the government-run nature of the collective. This article then makes and elaborates the proposition of the privatization of rural land to peasants. It also analyzes the government's land rights in private ownership of land and refutes the popular arguments against the privatization of rural land.
\end{abstract}

\title{
Keywords
}

land system; Household Contract System; lease; collective ownership; property rights; peasant private ownership 


\section{INTRODUCTION}

Rural land is owned by the collectives. The collective-owned land is contracted (in essence, tenanted) and farmed by the collective members. The remaining (output minus rent minus taxes) goes to the peasants. This is main content of China's current rural land system (the Household Contract System). In the system, the peasant-owned exclusive residual claim ${ }^{1}$ stimulates peasants' enthusiasm to work, which overcomes the members' shirking in the People's Commune (See section 3.1). In the 1980 s, the system promoted a rapid increase in agricultural output, supporting the rapid growth of China's economy.

But since the late 1990s, China's current rural land system gradually exposed serious drawbacks, mainly including instability of the peasants' land use right and insecurity of income right weakening peasants' enthusiasm for investment in land, and a lot of restrictions on the transfer of peasants' land leases obstructing the flows and optimized allocation of labor, land and capital (See chapter 2). Much has been written about its drawbacks. Researchers have proposed different reform schemes on China's rural land system: first, the improvements to the current rural land system in the framework of the collective ownership. Some people advocate peasants' emphyteusis and transfer rights over the emphyteusis (Chi, 2002; Zhang, 2002; Dang, 2002). Some people propose to change the three-level (town, village, Villager Group) collective ownership into the village collective ownership (Xiao, 1999; X. Zhang, 2013). Some people advocate Co-ownership by Shares (Han, 2004). Some people propose land stock cooperative system (the collective land is converted into shares of individual peasants; the peasants have the rights to income and transfer over land stock) (Shu, 2006; Wang, 2013). These improvements can, to varying degrees, ease but not eliminate the drawbacks of China's current rural land system fundamentally, for example, the collective violating peasants' land rights by virtue of its monopoly position in the Household Contract System (See section 2.1.2).

Second, nationalization and peasants' emphyteusis (Du, 2003, p. 207; Zhang, 2003; Zhou, 2004). Nationalization can greatly reduce the collective ability and chance to encroach peasants' land rights. Peasants' emphyteusis overcomes the instability of land use rights. But this system faces a multi-agent problem (governments at all levels exercise ownership on behalf of the state), while it may strengthen the government's role, and weaken the market's role in the allocation of land resources.

Third, privatization of rural land to peasants (Yang, 2002; Cai and Fang, 2005; Zhou, 2006, p.92; Wen, 2008; Yu and Chen, 2008; Qin, 2009). This proposal caused a great deal of misunderstanding and criticism.

In this article, we argue that the Household Contract System is essentially a lease where the collective (landowner) leases its land to its members to independently

1 As discussed in section 2.1.2 (2), in the system, the collective monopoly on rent formulation results in increasing land rent, which severely weakens the peasants' residual claim. 
farm. The drawbacks of China's current rural land system (the Household Contract System) result mainly from the collective ownership and the government-run nature of the collective. Based on this understanding, we advocate the privatization of rural land to peasants. ${ }^{2}$

This article begins with an analysis on the drawbacks of China's current rural land system from the perspectives of contract, property rights and resource allocation. We then present and clarify our proposition on the reform of rural land system. Then we refute some of the arguments against the privatization of rural land.

\section{THE DRAWBACKS OF CHINA'S GURRENT RURAL LAND SYATEM}

Since the late 1990s, China's current rural land system exposed serious drawbacks.

\subsection{Instability of the Peasants' Land Use Right and Insecurity of Income Right}

\subsubsection{Continuous adjustment of the peasants' Contracted Land}

It's necessary to adjust the members' Contracted (Tenanted) Land and amend land leases with the changes in the collective population in a lease period, because the collective members have an equal right to contract (in essence, tenant) the collective-owned land. But this adjustment inevitably sacrifices the stability of the peasants' land use right. According to a survey in 2008, the peasants' Contracted Land of 63.7 per cent of the surveyed villages was adjusted during 1997 to 1999; and 34.6 per cent after 1999 (Dou, 2013).

2.1.2 Collective monopoly in the Household Contract System

With no competitors as the only lessor, the collective is in a monopoly position in the Household Contract System, which is mainly manifested in the following two cases. (1) Some collectives forced peasants (lessee) to transfer their land leases (land contract rights). According to a survey in 2011, 64.04 per cent of the leases where businesses rent peasants' Contracted Land were signed under the pressure of the village committee or township government (Ye and Tian, 2013).

(2) The collective monopoly on land rent formulation. Until 2006, peasants had to pay two kinds of fees: First, the clearly defined agricultural tax, which was canceled 1 Jan. 2006. Second, the ill-defined land rent, which seriously weakened the income rights of peasants. Statistically, in China from 1996 to 1999 the peasants' per capita fees (excluding volunteer work) amounted ¥ 126.60, Ұ 143.90, Ұ 152.8०,

2 As discussed in section 2.1.2 (2), in the system, the collective monopoly on rent formulation results in increasing land rent, which severely weakens the peasants' residual claim. 
$¥ 14,0.10$ (L. Zhang, 2013), accounting for 13.26 per cent, 14.74 per cent, 15.87 per cent, 15.26 per cent of per capita agricultural net income of rural residents respectively (NBSC). And the burden on peasants in many regions is well above the national average. According to the survey of Cao (2000) on two villages in Yongxing County, Hunan Province, in $\mathrm{H}$ village per capita fees amounted to $¥$ 179.01, accounting for 50.23 per cent of per capita agricultural income; in B village per capita fees amounted to $¥ 238.70$, accounting for 69.18 per cent. In a competitive land tenure market, land rent is determined by the competition and negotiation between the lessor and the lessee. However, in the Household Contract System, the collective is a monopolist of rent formulation, while the peasant is just a recipient of land rent, which is why there has been an increasing land rent before 2006.

\subsubsection{Government monopoly in supply of urban construction land and in land expropriation}

Since the 1990s, the government's enclosing land has been intensifying for the following reasons. Firstly, most of the land whether for public interest or non-public interest in urbanization can only be the land expropriated by the government, because the collective land can not be transferred for non-agricultural construction (Article 63, Land Administration Law of the PRC). The legal restrictions on the purpose of the public interest of the expropriation (Article X, The Constitution of the PRC) are like an empty text.

Secondly, the benefit from the price difference between land expropriation and sale is the power of the government enclosing land. On the one hand, the collective land can not be transferred for non-agricultural construction. Any organization or individual can only apply for state-owned land to meet its or his demand for construction land (See Article 43, Land Administration Law of the PRC). These provisions establish a government monopoly on urban land, which leads to more expensive urban land. China's Land Resources Bulletin shows that China's urban land prices have been rising since 2001. The average annual growth rate of the average land price in major cities was 5.36 per cent from 2001 to 2012. The average land price in 105 major cities amounted to $¥ 3129 / \mathrm{m}^{2}$ in 2012 .

On the other hand, China's current rural collective is a government-run organization established by the government in the 1950s, not a free union of peasants. It is still largely subordinate to the government, though nominally self-governed so far, which determines the government monopoly in the expropriation of collective land, because a collective subordinate to the government can not (individual peasants without the right to freedom of association are less likely to) reciprocally negotiate with the government. The government monopoly in the expropriation of collective land leads to a cheap land compensation. According to a survey in 2011, in the land expropriation the average compensation that the village collective got was $¥ 24,980$ / 
$\mathrm{Mu}\left(\mathrm{1Mu} \approx 666.7 \mathrm{~m}^{2}\right)$, landless peasants got only $¥ 17,256 / \mathrm{Mu}$ (Ye and Tian, 2013), only 3.21 per cent and 2.22 per cent of the average price that the government sold land respectively.

The government's growing enclosure of land has consequences. Firstly, it intensifies instability of the peasants' land use right. According to a survey, 43.26 per cent of the villages experienced land expropriation since 1995 (Ye and Tian, 2013).

Secondly, a lot of farmland is enclosed. Alarge number of peasants lose land and become unemployed refugees. The expropriated land only for the urban construction amounted to 20.97 million $\mathrm{Mu}$ (1.398 million hectares) only from 2004, to 2012 (NBSC), which caused landless peasants estimated at about 15 million. The transfer of employment is difficult for landless peasants because they are mainly elderly peasants with little education (in China today, most literate young peasants work in the city). According to the survey, the unemployment rate in the landless peasants amounts to 25.92 per cent $(\mathrm{Xu}, 2013)$.

Thirdly, illegal events and mass incidents occur frequently in the government's growing enclosure of land, endangering social stability. The lack of effective constraints on government results in a lot of illegal events in the expropriation, transfer, and the use of land. According to China's Land Resources Bulletin, 626, 032 cases on illegal land use were found, involving 4,14,163 hectares of land, from 2006 to 2012. The criminal officials reached 3297 only in the special land inspection from 2007 to 2011. Peasants are often forced to take drastic measures, such as group resistance, to defend their rights because of government monopoly in the land expropriation. According to Social Blue Book published by China's Academy of Social Sciences in 2013, nearly half of tens of thousands of pieces of mass incidents in China each year resulted from the land expropriation.

Fourthly, cheap compensation in land expropriation leads to inefficient use of land. From the land productivity, statistically, Shenzhen, Shanghai, Guangzhou are ranked as the top three in China, but Shenzhen's just 1/5 of Singapore's, 1/10 of Tokyo's; Shanghai's just 7 per cent of Tokyo's, 24 per cent of Paris's, 27 per cent of Seoul's; Guangzhou's just 1/17 of Hongkong's, 1/18 of Singapore's, 1/32 of Seoul's (Yu, 2013).

Instability of the peasants' land use right and insecurity of income right above weaken peasants' enthusiasm for investment in land. According to a survey in 2011, only 3o.11 per cent of the surveyed peasants made medium- and long-term investments in their Contracted Land (Ye and Tian, 2013).

\subsection{China's Current Rural Land System Conflicting with the Optimized Allocation of Resource}

In China's current rural land system, a peasant's right to contract (tenant) the collective-owned land is based on his status as a member of the collective (See Ar- 
ticle 14, of Land Administration Law of PRC). If a peasant quits the collective and becomes a city resident with a non-agricultural household registration, he would have to freely return his Contracted Land to the collective, because he is no longer a member of the collective and has no right to contract the collective-owned land (See Article 26, Land Contract Law of PRC), which constitutes a cost of rural surplus labor to urban residents. Because of this cost, a lot of new city migrants from the countryside still retain agricultural household registration. In China in 2011, this population was about 311.5 million (the rural population was 656.6 million, while the population with agricultural household registration amounted to 968.1 million (NBSC)).

The right to transfer is a prerequisite for the optimal allocation of resource. The peasants' right to transfer their land leases is subject to a lot of constraints in China's current rural land system. (1) Agricultural use of land is not allowed to be changed in the transfer of the land leases. (2) The transfer deadline can only be limited to the remaining term of leases. (See Article 33, Land Contract Law of PRC). (3) Even without changes in agricultural use of land, the land lease can not be transferred without the consent of the collective (See Article 37, Land Contract Law of PRC), which gives space for the collective invading peasants' right to transfer. And the land lease can only be transferred to peasants (Article 4,1, Land Contract Law of PRC), which hinders the non-agricultural capital flowing to agriculture. (4) The land leases not in a same collective can not be interchanged, even if the interchange is helpful for farming (See Article 4, , Land Contract Law of PRC), which hinders a decline in the cost of farming. (5) The land lease cannot be mortgaged (Article 184, The Property Law of the PRC), which limits the ability of peasants' financing.

These restrictions make the transfer of the land lease very difficult. And the transfer value is very low, because as mentioned, the peasants' land leases are in insecurity, facing the usurpation of the government, collective, and officials at any time (See section 2.1). A large number of peasant-workers go to town to work in agricultural slack season and come back to farm in agricultural busy season or simply let their Contracted Land barren, because they cannot find the transferee, or because the transfer value is too low. According to the survey, barren land accounted for 10 per cent of farmland in Hunan province in 2007 , even 40 per cent in some villages, such as Binhu village in Hubei province (Yu, 2013). And the peasants' concurrent-business is very costly - the cost and time for going to town and back.

The expensive urban land resulting from the prohibition of the transfer of collective land for non-agricultural construction (See section 2.1.3) keeps up house prices and rents in cities in China today, which raises the cost of living in the city and hinders the transfer of rural surplus labor. The average price of housing in China rose from $¥ 1948 / \mathrm{m}^{2}$ in 2000 to $¥ 5429.9 / \mathrm{m}^{2}$ in 2012 (NBSC); the price is much higher in big cities, such as in Peking - $¥ 16,55^{3.5} / \mathrm{m}^{2}$ in 2012 (NBSC), with an increase of about 178.7 per cent, and an average annual growth rate of about 14.9 per cent. In 
2012, per capita disposable income of urban households - Ұ 24564.7 (NBSC) and per capita income of peasant-workers - $¥ 26988^{3}$ are only enough to buy housing of about $4.5 \mathrm{~m}^{2}$ and $4.97 \mathrm{~m}^{2}$ respectively if not used for consumption.

\section{THE DIRECTION OF REFORM}

The direction of reform of China's current rural land system is the peasant private ownership.

\subsection{Abolishing Collective Ownership}

Potential agricultural contracts include three categories: (1) wage contract, (2) fixed rent contract, (3) share contract (including input share contract, output share contract, and a mix of the both). The transaction cost of the three types of contracts is greatly increased, and their efficiency is reduced in the collective ownership of rural land compared with that in the private ownership of the land. In the agricultural wage contract (The People's Commune in China in the 1950s to 1970s can be seen as a wage contract in the public ownership of land and other important agricultural means of production ${ }^{4}$ ), it is difficult to measure the individual's labor contribution, because agricultural output is affected by many factors such as land, labor, climate and pests (Barzel, 1997, p.42-5). Accurately paying wages according to the labor contribution is impossible. Therefore, the members have a strong incentive to shirk. The effective supervision is a necessary condition for the efficiency of the agricultural wage contract. The supervisors having residual right is a necessary condition enough for the effective supervision. However, in the wage contract under the collective ownership of rural land, the incentive effect of the residual right for the supervisors is weak, because the residual right belongs to the collective, which results in a lack of supervision and an inefficient agricultural wage contract.

In the fixed rent contract, the peasants' enthusiasm to work is high, because they exclusively have the residual right (G. He, 2013), which overcomes the problems of high supervision cost and employee's shirking in the wage contract. But the preceding analysis shows that the lease in the collective ownership of land has serious drawbacks (See chapter 2).

In the collective ownership of land the share contract and the fixed rent contract have the same drawbacks because of the same factors, but the share contract is rare

3 Based on the average monthly income of peasant-workers in the third quarter of 2012 (NBSC).

4. The difference is that the contract is a voluntary relationship, but the People's Commune is a forced, not a voluntary association of members. The lifetime of members is under the control of the People's Commune. Therefore, the People's Commune is essentially a forced slavery. Nevertheless, it will be seen that the notion of contract is useful in analyzing the People's Commune. 
because its transaction cost is much higher than the wage contract's, and the fixed rent contract's in the modern.

The transaction costs of all possible agricultural contracts are higher, the benefits of land lower, and there is more rent dissipation in the collective ownership of land than in the private ownership of land. Therefore, abolition of the collective ownership of rural land is the requirement to improve the benefits of land and reduce the rent dissipation.

\subsection{Privatization}

The main reasons for privatizing rural land to peasants can be summarized as follows: (1) in the peasant private ownership, land rights are clear. And the peasants can protect their land rights from violations of the collective, government and officials in accordance with the law. Thus, they have enthusiasm to invest in the land.

(2) The right to transfer is a prerequisite for optimal allocation of resources. And assets that can be transferred free must be private property. In China today a large number of rural surplus labors, small-scale family-farming (diseconomies of scale), and lack of capital are the main obstacles to increasing the income of peasants and developing agriculture. Overcoming these obstacles is actually equivalent to optimal allocation of labor, land and capital. In peasant private ownership of land, the peasant-workers can sell or lease their land if they have this intention, which avoids the cost of peasants' concurrent-business (the cost and time for going to town and back) and the loss of barren land (net income of farming or rent). And the revenue from land sales or rent provides capital and security for peasant-workers. The right to transfer over land is particularly important for the peasants without the ability to work. The revenue from land sales or rent may be their most important, even only source of income. The peasants can get much-needed funds by selling or mortgaging land. Those peasants with a comparative advantage in agriculture can enlarge their farm through the purchase or lease of land. Non-agricultural capital can flow into agriculture through the purchase or lease of land. Thus, the rural surplus labors gradually flow from agriculture. Land is gradually concentrated to individuals and organizations with a comparative advantage in agriculture. The obstacles to increasing peasants' income and developing agriculture in China today are gradually surmounted. In addition, the peasants' right to transfer their land for non-agricultural construction freely in the peasant private ownership of land will break the government monopoly on urban construction land in the current land system, which will help in reducing urban real estate land prices and rents (a cost of the transfer of rural surplus labor), and help the transfer of rural surplus labor.

Generally, there are two ways of privatizing rural land to peasants. One is to directly convert the tenancy right into ownership of peasants over their current Con- 
tracted Land, homestead, and Reserved Plots ${ }^{5}$. The other consists of two steps: to adjust the peasants' existing Contracted Land, and then to convert the tenancy right into ownership of peasants. As for which way to take, and how to adjust if the second option is selected, these issues should be left to peasants themselves to choose (Qin, 2009), for example, to decide by vote in the village.

\subsection{The Government's Land Rights}

The government's land rights mainly include the following aspects.

(1) The right to tax land. Taxing land is both an economic right of the government, and an important mean of the government to improve the efficiency of land use and reduce waste land. The government is entitled to re-introduction of agricultural tax if necessary, although agricultural tax is canceled in China on January 1, 2006. Moreover, the government can levy real estate tax, after the privatization of rural land. In urbanization, a large part of the land appreciation results from the government investment in urban infrastructure. A part of the appreciation, therefore, should go to the government. After the privatization of rural land, the government can get a part of the appreciation through the imposition of land transaction tax and VAT (Wen, 2008).

(2) The right to levy land. Some people believe that the private ownership of land may harm the public interest, because the landowner may charge the buyer too much in the land transfer for the public interest. Thus they oppose the privatization of rural land. Actually, this fear is not necessary, because in case that an agreement between the government and the owner could not be reached, the government can apply for court compulsory expropriation in the land expropriation for public interest.

Compared with the private right, the public right is strong. In the land expropriation, it is necessary to impose restrictions on the government's expropriation power to prevent the public power from damaging the private right. First, the government's expropriation of private land should be restricted to the purpose of public interest. Land outside the purpose of public interest should be allocated directly by the market. (Zhang, 2012)

Second, the government cannot deprive any person of life, liberty, or property, without due process of law. From foreign experiences, due process of law should be defined as follows: the land expropriation authority can issue a compulsory purchase order only after a public inquiry and hearing, and approved by the State Council; the court has the power to review the legality of the exercise of the expropriation power; the dispute shall be submitted to the Land Court and subject to judicial judgment when a compensation dispute between the expropriation authority and the landowner appears and an agreement cannot be reached.

5 The Reserved Plots are the small plots of land left to the commune members to use in the long-term in the Agricultural Collectivization Movement in China in the 1950's. The peasants have the rights to lifelong use and income, but have no right to transfer over this part of the land. This part of the land is exempt from the rent and taxes. Its output is entirely owned by the peasant. 
Finally, the government cannot expropriate any private property for public use, without reasonable compensation. The compensation should be exactly equal to all losses of the owner in the expropriation, in consideration of all relevant factors, including the use, history, market value of the land, increase in value resulting from the government investment, purpose of expropriation, et al.. This compensation must be higher than the compensation unilaterally decided by the government in the current land expropriation system (See section 2.1.3), which helps in saving land and improving the efficiency of land use. The restrictions on the purpose of land expropriation and the increase in costs of land expropriation can effectively curb the government enclosing land.

(3) The right to regulate land use. The government has the power to regulate the use of land for the public interest. The government mainly uses plan and law, including local and national plans and regulations of land use, environmental regulations, building regulations, et al., to regulate the use of land.

(4) The right to inherit the real estate without successor. The real estate without legal successor goes to the government on the death of its owner.

\section{MISUNDERSTANDINGS OF THE PRIVATE OWNERSHIP OF RURAL LAND}

Misunderstandings of the private ownership of rural land are a major obstacle to privatization. They mainly come from the following aspects.

\subsection{The Relation between the Private Ownership of Land and Social Stability}

The opponents of the privatization of rural land to peasants, such as Wen (2013), Jian (2013), and et al., believe that once the rural land is privatized to peasants, a large number of peasants may sell their land due to moving into the city in search of work (some may sell their land in great need of funds; some without the ability to work may live on the revenue from land sales; some may even sell their land because of laziness). Once they fail to find work and run out of their savings, these landless peasants will become unemployed refugees who may endanger social stability. Opponents therefore argue that the peasant private ownership of rural land is harmful, and oppose the privatization of rural land to peasants.

This view is baseless. It asserts that the peasants are irrational and lack the capacity to make decisions. Actually, most peasants will not blindly sell their land in the peasant private ownership of land precisely because they are rational. The choice is a trade-off for a rational peasant. If he chooses to sell his land, it shows that he has no other better choice. The peasants who sell their land because of laziness are rare. A rational peasant may sell his land only when there is a comparative advantage in non- 
agricultural industries compared with that in agriculture, and only when he believes that he will have a stable non-farm income sufficient to sustain his life in future. The free trade of land in the private ownership of land, therefore, may bring unemployed refugees, but not quite a lot. Moreover, unemployed refugees should get social assistance, unless the reason is laziness. Thus, the fear that the free trade of land in the private ownership of land may bring a large number of unemployed refugees, thus threatening social stability, is misplaced. The opponents of the privatization of rural land to peasants also often prove their aforementioned view by using the following historical theory: peasant wars in China's history are essentially landless peasants' revolution against landowners to get land; the free trade of land in the private ownership of land resulted in a large number of landless peasants. According to Qin (2001, 2007), this theory is inconsistent with historical reality. Firstly, peasant wars in China's history mainly resulted from the rulers' heavy exploitation (taxes) of smalland medium-sized landowners. The main participants in peasant wars were mainly small- and medium-sized landowners rather than landless peasants. Secondly, the main reason for a large number of peasants selling their land was unbearable heavy land tax. Purchasers of land were mainly the tax-free privileged class.

\subsection{Security Function of Land}

Some opponents of the privatization of rural land to peasants argue that China's current rural land system plays an important role in security for peasants. For example, unemployment peasant-workers can return to the countryside to farm (the equivalent of unemployment insurance); older peasants can live by farming (the equivalent of old-age security). However, a large number of peasants may sell their land, losing security, once the rural land is privatized to peasants (X. Zhang, 2013). This view is wrong. First, China's current rural land system does play some role in security for peasants, but no one can deny that the peasants should enjoy equal social security with urban residents. Second, as mentioned, the peasant private ownership of rural land will not result in a large number of peasants selling their land blindly. The third, in China's current rural land system, a lot of constraints on the peasants' right to transfer their land leases make the transfer very difficult and the transfer value very low, which severely limits the security function of land to peasants. Poor peasants cannot get much-needed medical funds by transferring their land leases. Those peasants without the ability to work cannot live on the revenue from the transfer of land leases. The fourth, the security function of land to peasants does not exclude the peasant private ownership of land; on the contrary, it requires the peasant private ownership! In the peasant private ownership, poor peasants can get muchneeded medical funds by selling or mortgaging their land, and the peasants without the ability to work can live on the revenue from land sales or rent. Finally, it is necessary to control land in peasants' hands to restrict the collective, government, and 
officials from violating their land rights, precisely because land is important for most peasants in China today (Qin, 2009).

\subsection{The Relation between the Private Ownership of Land and the Interests of Peasants}

Some opponents of the privatization of rural land to peasants believe that with the expansion of peasants' land rights, reaching an agreement on rural public goods among peasants becomes more difficult. The expansion of peasants' land rights, therefore, would undermine the rural collective ability to provide public goods for peasants and harm the interests of peasants (X. He, 2013). Whether it is so or not, it is necessary to perceive the practical role of the collective in China's current rural land system. In China today, the rural collective is a government-run, not autonomous organization, whose main responsibility is to execute government decisions such as assisting the government in land expropriation. Although some rural collectives may provide some services, such as market services, technical services, and et al. for peasants, their role in this area is weak. Moreover, as mentioned, the rural collective often violates peasants' land rights. The peasant private ownership of rural land can curb the government, collectives and officials from violating peasants' land rights (See section 3.2). It is therefore helpful to peasants in general, even though it can weaken the collective ability to provide public goods for peasants. Moreover, the collective is not an efficient organization to provide rural public goods. Peasants can cooperate to provide public goods on their own. Provision of rural public goods is also an important duty of the government.

\subsection{The Relation between the Private Ownership of Land and Farmland Preservation}

Some opponents of the privatization of rural land to peasants believe that the peasant private ownership can lead to excessive farmland for non-agriculture, endangering food security (X. Zhang, 2013; Jian, 2013). This fear is not necessary. In China today the main cause of many non-agriculture farmlands is government's enclosing of land, not the peasants' using or transferring farmlands freely. The peasant private ownership of rural land can curb the government enclosed land (see section 3.2), and is helpful for the protection of farmland and food security. Meanwhile, the market can effectively allocate land between agriculture and non-agriculture. If excessive land for non-agriculture results in the shortage of agricultural products, the price of agricultural products will rise and that will automatically curb the land used for non-agriculture. In a market economy, the government should improve the value of land for agriculture by using agricultural subsidies to protect farmland, not simply to restrict, or even deprive the peasants' rights to use and transfer land. 


\section{CONCLUSION}

The Household Contract System based on the collective ownership is the main content of China's current rural land system. It is essentially a lease where the collective (landowner) leases its land to its members to independently farm. The peasantowned exclusive residual claim in the lease stimulates peasants' enthusiasm to work, which overcomes the members' shirking in the People's Commune. The Household Contract System, therefore, is efficient compared with the People's Commune.

But since the late 1990s, China's current rural land system gradually exposed serious drawbacks, mainly including instability of the peasants' land use right and insecurity of their land income right weakening peasants' enthusiasm for investment in land, and a lot of restrictions on the transfer of peasants' land leases obstructing the flows and optimized allocation of labor, land and capital.

The drawbacks of China's current rural land system result mainly from the collective ownership and the government-run nature of the collective. The improvements to this system in the framework of the collective ownership, therefore, can not eliminate the drawbacks of this system fundamentally, and may make land ownership more unclear, and the transaction cost higher. And the state ownership of rural land faces multi-agent problem (governments at all levels exercise ownership on behalf of the state), while it may both strengthen the government's role, and weaken the market's role in the allocation of land.

Direction of the reform of China's current rural land system is the peasant private ownership. In the peasant private ownership, land rights are clear. And the peasants can protect their land rights from violations of any organization or individual in accordance with the law. Thus, they have enthusiasm to invest in land. Moreover, the right to free transfer over land is a prerequisite for optimal allocation of land, labor and capital resources (land flowing to individuals and organizations with a comparative advantage in agriculture; labor and capital flowing between agriculture and nonagricultural industries). And the land that can be transferred free must be private land.

The misunderstanding of the private ownership of land and the resistance from the vested interests in the current rural land system are the main obstacle to privatize rural land. The reform cannot come and succeed, until the strength of the supporters of the reform is over opponents'. Currently, it is necessary to carry out a broad discussion on the reform of the land system in order to accumulate strength to privatize rural land. In the discussion there will be more people (especially the decision-makers) to recognize the necessity and feasibility of rural land privatization, and to become the supporters of the reform. With the rise of supporters' strength, even some vested interests in the current rural land system may also support the reform due to pressure or the awareness of the reform trend. 
Acknowledgments: We are grateful to anonymous referees and the editor who helped to improve this paper very significantly. All errors are our own. This work was supported by the [Hainan Natural Science Foundation] under Grant (No. 714265) and [Middle-west Universities' Enhancing Comprehensive Strength Project, Hainan University]. 


\section{REFERENCES:}

Barzel, Y., Economic Analysis of Property Rights, Chinese version (translator: F. Fei and Y. Duan). Shanghai: Shanghai People's Publishing House, (1997)

Chi, F., Giving Peasants Land Use Rights. Peking: China Economic Press, (2002)

Cai, J., Fang., C., "A Comparative Analysis of the Schemes of Rural Land System Reform", Social Science Research, 4, (2005): 28-32

Cao, L., "A survey on peasant's burden”, The World of Survey and Research, 11, (2000): 28-30

Dang, G., "Market-oriented Reform of the Rural Economic System", China Rural Survey, 4, (2002): 72-9

$\mathrm{Du}, \mathrm{R} .$, "Resource Endowments-the Contradiction between Population and Land-Determine China's Rural Land System", in China in Transformation, Peaking: Social Science Academic Press (2003)

Dou, X., "An Exploration on Innovation of China's rural Land System Based on the Perspective of the Rights", Theoretical Investigation, 1, (2013): 94-7

Han, J., "Attaching the Property Rights to Peasants' Contract Rights", Guangming Daily, Jul 27.2004.

He, G., "The Rise and Fall of Serfdom in China: A Theory of Institutional Change", Economic History of Developing Regions, 28(1), (2013): 69-86

He, X., "Reply to Professor Zhou Qi-ren on Logic of Land Ownership", Journal of Huazhong Agricultural University (Social Science Edition), 3, (2013): 1-9

Jian, X., "An Analysis on the land privatization in China", Contemporary Economic Research, 1, (2013): $17^{-25}$

NBSG (National Bureau of Statistics of China), Per capita agriculture net income of rural residents, People's lives; The Area of the Expropriated Land, Urban Construction, City Overview; Total Population; Rural Households and Rural Population, Agriculture; Average Price of Housing Sales Based on Use of Housing, Investment in Fixed Assets and Real Estate; Per Capita Income of Urban Households and Engel Coefficient, People's Lives; Peasant-workers, People's Lives. http://data.stats.gov.cn/workspace/index;js essionid=02FB31F69E988949 ${ }_{9} \mathrm{CE} 6 \mathrm{~B}_{5} \mathrm{D}_{4} \mathrm{BC}_{7} 62{ }_{2} \mathrm{~F} 8 \mathrm{D}$ ? $\mathrm{m}=$ hgnd)

Qin, H., "On Land Problems", The Economic Observer Newspaper, Feb 9 (041), (2009)

Qin, H., "Optimal Allocation and Land Benefits", The new Finance and Economics, 9, (2001): 66-7.

Qin, H., "A discussion on some problems of traditional tenancy system", China Rural Survey, 3, (2007): $27-40$

Shu, J., "On How to Overcome the Drawback of the Ill-defined Owners of Rural Collective Land", Journal of the Party School of the Central Committee of the C.T.C., 3, (2006): 47-50

Wang, R., "Urbanization and the Reform of China's Rural Land Property System", Journal of the Party School of the Central Committee of the C.T.C., $17^{(1)},(2013): 89^{-9} 9^{2}$

Wen, G. J., "Market Deformity, Social Conflict and the Current Land System", Comparative Economic \& Social System, 2, (2008): 45-51

Wen, T., "Why can't rural land be privatized in China", Gansu Agricultural Sciences, 3, (2013): 10-11

Xiao, F., "Defects and Improvement of the Collective Ownership", Peking University Law Journal, 4, (1999): $86-90$ 
$\mathrm{Xu}, \mathrm{Q}$., "A policy suggestion on promoting employment of landless peasants in urbanization", Scientific Development, 2, (2013): 24-27

Yang, X., "Xiaokai Yang's Talk with Rushan Jiang: Deep Problems Faced by China's Reform: the Reform of Land System", Strategy and Management, 5, (2002): 1-5

Yu, J., Chen, Z., "Returning Peasants the Land Rights", Southeast Academic Research, 2, (2008): 12-8

Yu, M., "The land waste should be curbed", Finance \& Economy, 4, (2013): 7-9

Ye, J., Tian, C., "The Status of China's Rural Land Rights: Contract Structure, Institutional Change and Policy Optimization", Journal of Huazhong Normal University (Humanities and Social Sciences), 52 (1), (2013): $38-4.6$

Zhang, H., "Changes in China's Rural Land System", Peking: China Agriculture Press, (2002)

Zhang, X., "On the Reform of China's Rural Land Ownership Based on Civil Law", West Forum, 23(1), (2013): $11-6$

Zhang, D., "On the New Land Tenancy System", Forward Position in Economics, 4, (2003): 36-8

Zhang, L., "The peasants' burden and financial support for agriculture", Sub National Fiscal Research, 4 , (2013): 16-22

Zhang, M., "Alienation and Restriction of the State Eminent Domain", Hebei Law Science, 3o(10), (2012): $61-7$

Zhou, T., "Comparison and Selection of the Schemes of Rural Land System Reform", China Economic Times, Feb 26.2004.

Zhou, Q., "Income Is a Series of Events", Peking University Press, (2006) 
